\author{
Mariola Konopko \\ mgr inż. \\ uczestnik studiów doktoranckich \\ na Politechnice Białostockiej \\ (dyscyplina Budownictwo) \\ mariola.konopko92@gmail.com
}

\author{
Malgorzata Ewa Wysocka \\ mgr inż. \\ Politechnika Białostocka, Zakład Geotechniki \\ m.wysocka@pb.edu.pl
}

DOI: 10.35117/A_ENG_18_02_04

\title{
Organic subsoil assessment using GPR method
}

\begin{abstract}
In the design and realisation process of the linear objects it is extremely important to identify ground properties and specify the extent of the complexity of hydrogeological conditions. Aiming at detailed site identification as well as proper discontinuity and anomaly detection is impossible in the light of the point character of geotechnical investigations. In order to deal successfully with such impediments, various non-invasive geophysical methods, including the ground penetrating method, are worth using. The analysis carried out proves that the GPR technique can be used for illustrating the boundaries of the organic layers in the subsoil.
\end{abstract}

Keywords: Ground penetrating radar method (GPR), Non-invasive ground investigation, Organic soils

\section{Introduction}

The presence of organic soils in the substrate, with the simultaneous occurrence of a high level of groundwater, requires the use of appropriate ground improvement. Proper selection of reinforcement requires, however, a very accurate recognition of the conditions prevailing in the substrate. In the case of linear objects, such as communication routes, classical field tests may not provide enough information, especially between research points.

The GPR (Ground-Penetrating Radar) method is one of the geophysical methods that provides non-destructive information on the construction of the ground surface and the location of subsurface objects. The research is based on electromagnetic technology, based on the emission of electromagnetic impulses at high frequencies excited by artificial means, and registration of waves reflected from the boundaries of centers with different properties [8]. The signal, passing through successive layers of differing properties, changes. The waves may be subject to such phenomena as: reflection, refraction, interference, diffraction, resonance or damping, while the analysis of these changes makes it possible to recognize the ground [9]. In addition, the more pronounced the difference in relative parameters between the two materials, the easier it is to observe the change in the propagation of electromagnetic wave at their boundary.

\section{Principles of the GPR method}

The features of the substrate that have the greatest impact on the propagation of the electromagnetic wave are magnetic permeability, dielectric permittivity, and conductivity of the medium. The mentioned parameters may vary significantly depending on the lithological 
structure of the substrate and its chemical composition, porosity and wateriness, degree of looseness or salinity [3]. However, the basic factor that characterizes the electromagnetic field is absolute electrical permittivity, i.e. dielectric permittivity. In practice, a relative parameter is commonly used, also referred to as a dielectric constant [1]. It is the ratio of the electrical permittivity of the material to the electrical constant, i.e. the electrical permittivity of the vacuum (1):

$\varepsilon_{r}=\frac{\varepsilon}{\varepsilon_{0}}$

It is very difficult to take into account the influence of various factors on the electrical properties of the studied centers. Experimental research, however, allowed approximate determination of the dielectric constant for various materials, which may vary from 1 to 88 , for example: loamy soil $4-15$, sandy-loam soil $4-20$, sandy soil $4-30$, water $78-88$, ice 3-8 [10].

The design of GPRs used in ground floor research consists of such elements as a transmitting and receiving antenna, a transmitter and a receiver, and a unit registering the central unit with a computer. The electromagnetic pulse excited by the transmitter and emitted into the ground by means of a transmitting antenna propagates in the medium, while the reflected impulse is registered by the receiving antenna and digitally processed in the receiver [2]. The central unit should enable control of the entire system operation, coordination of transmitter and receiver clocks, recording of amplitudes of the received electromagnetic wave and presentation of results in the form of echograms [3]. The antenna can be treated as an essential element of a GPR that ensures the proper accuracy of measurements. In addition to mono and bistatic antennas, there are also line and aperture antennas, shielded and unshielded antennas. Currently, shielded antennas are most often used, the main advantage of which is the orientation of the generated electromagnetic pulse. Antennas working in georadars can also be distinguished in terms of the bandwidth of the emitted signals.

GPR measurements should be carried out in such a way as to obtain the most accurate information about the tested medium and at the same time eliminate as much as possible any errors [7]. The basic techniques of performing measurements using radar are reflexive profiling, velocity profiling, screening and well logging [10]. The use of reflective profiling, velocity profiling or x-rays does not fundamentally change the way the measurement is made. In each case, the antennas are moved along the assumed profile line, however, the obtained results are radically different [6]. During the simultaneous movement along the tested profile of the transmitting and receiving antennas, time sections are obtained, which after appropriate treatment show the geological structure of the ground [2]. In order to correlate the obtained information with the depth at which the obstacle occurs, the method of speed profiling should be used. It is necessary to determine the speed of the electromagnetic wave. Both techniques are therefore related to each other [5]. The main difference, however, is how to set up the transmit and receive antennas. In the case of reflective profiling, a parallel system of bistatic antennas located close to each other is usually used, which are then simultaneously moved along the planned route [7]. While it is possible to use monostatic antennas in reflective profiling, it is most convenient to use unscreened bistatic antennas in velocity profiling. The essence of the method is observation of reflective lines recorded during subsequent changes in the spacing of antennas.

The maximum depth range and the resolution of the GPR method depend largely on the predicted ground conditions and the antenna adopted for testing, the task of which is to excite the electromagnetic wave at a specific frequency. The maximum range of the GPR method is usually dependent on the predicted depth to which it is necessary to recognize the ground surface [4]. The signal emitted into the center is characterized by a specific frequency. The use of higher frequencies results in a reduction of the propagation range of the 
electromagnetic wave in the ground and at the same time increasing the accuracy of the measurements. At the same time, at lower frequencies, the impulse penetrates deeper, but only larger objects and clearer boundaries of works are visible. This dependence can be explained by the damping phenomenon, which increases with the increase of the wave frequency. The depth to which the excited energy arrives depends also on the length and speed of the electromagnetic wave, i.e. indirectly on the electromagnetic properties of the examined centers. The rate of movement of the equipment on the ground, which is selected depending on the measurement parameters, also has a significant influence on the obtained echograms. Inadequate speed or its sudden changes particularly adversely affect the measurements of the electromagnetic waves in the medium, because they disturb the angles of the reflected reflections. Reading disruptions may also result from inadequate adhesion of antennas to the terrain surface. This means that many factors influence the amount of signal loss propagating into the examined substrate.

The depth range of the georadar method is strongly related to its resolution. Distinguishing the searched objects, which lie along the vertical plane and perpendicular to the direction of the test, is called vertical resolution. However, when objects are located along the horizontal plane and parallel to the direction of the study, then one can speak about horizontal resolution [10]. Schematically, the above division is shown in Figure $\mathbf{1}$.

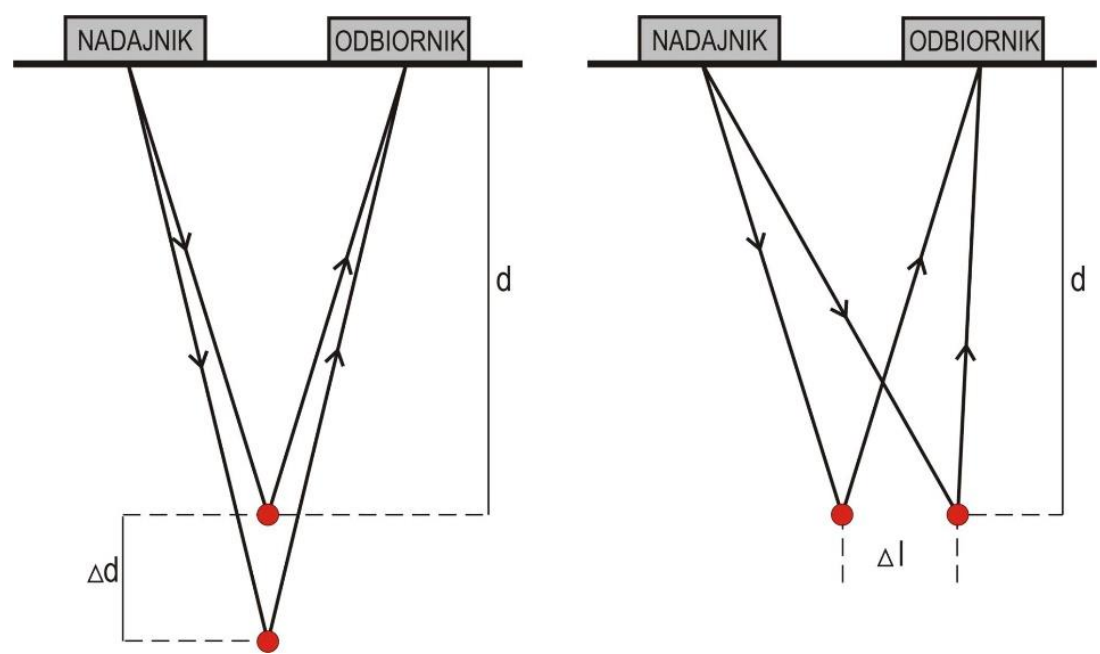

1. Vertical and horizontal resolution (based on [6])

\section{Location of research sections}

As part of the geomadetic soil study, geophysical profiling has been carried out, which is located within the planned municipal road reconstruction. The studied areas are located near the town of Ruda, in the Krypno commune, in the moniecki district, in the Podlasie voivodship. The exact location of the profiles made has been marked on figures 2 and $\mathbf{3}$. The analyzed road runs through flat rural areas, i.e. arable lands and meadows with loose singlefamily housing. Currently, it is partly a road with an asphalt surface (near profile No. 1), and partly a paved dirt road (near profiles 2 and 3 ). The appearance and technical condition of the roads included in the reconstruction plan is shown in photograph 4.

The studied areas are located in the eastern part of the Krypno commune, in terms of physical and geographical area, they are therefore included in the mesoregion of the Białostockie Upland and the North Podlasie Lowland macro-region. According to the information of the Central Geological Data Base, the stratigraphic structure of the area was affected by Middle-Polish Glaciations, as a result of which an old-glacial landscape, ie sand sands and gravels, developed. In addition, the analyzed areas belong to the Narew river basin, whose unique feature is its anastomotic character. Profile No. 1 is located near the Kulikówka 
watercourse, and profiles No. 2 and 3 - near the Jaskrana's watercourse. Changes in the location of riverbeds and the formation of oxbow lakes (information confirmed by the environmental intelligence) caused that in their vicinity in the Holocene such lands as sands, gravels and river rivers and organic soils (peat and silt) developed. Due to its origin, organic soils are deformable so they can not be a stable ground for the planned road. Leaving the peat layer in the substrate may result in uneven settling of the surface in the future and its accelerated destruction. Therefore, it is extremely important not only to recognize these lands, but also to determine the extent of their occurrence in a given area, the so-called their bouting.

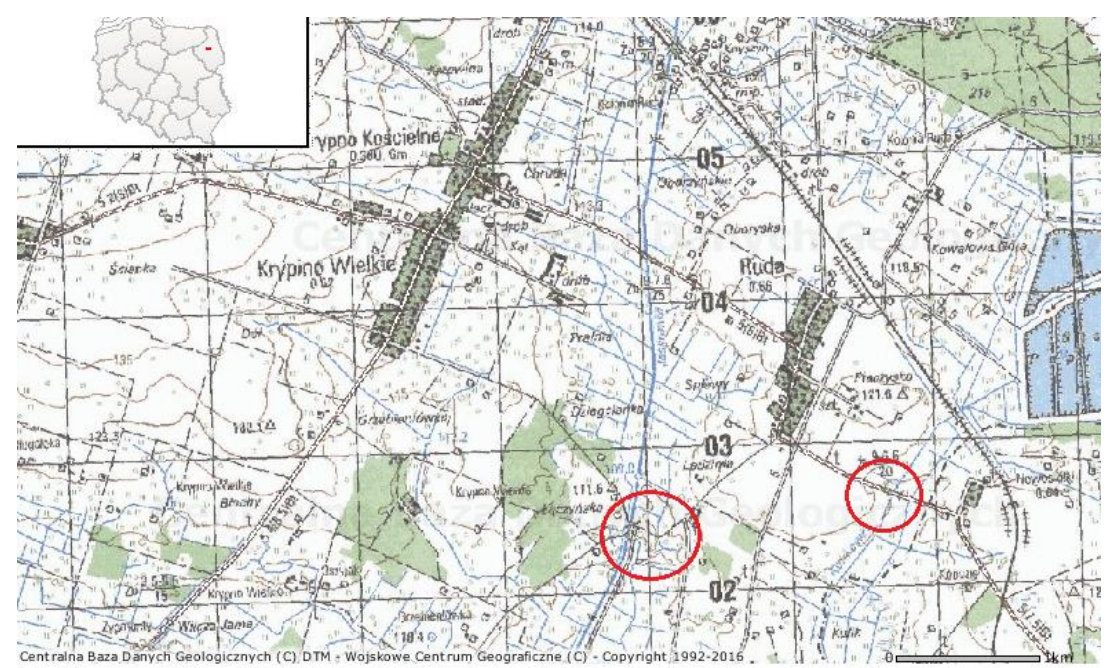

2. Topographic map with the location of the area covered by the interpretation (based on [11])

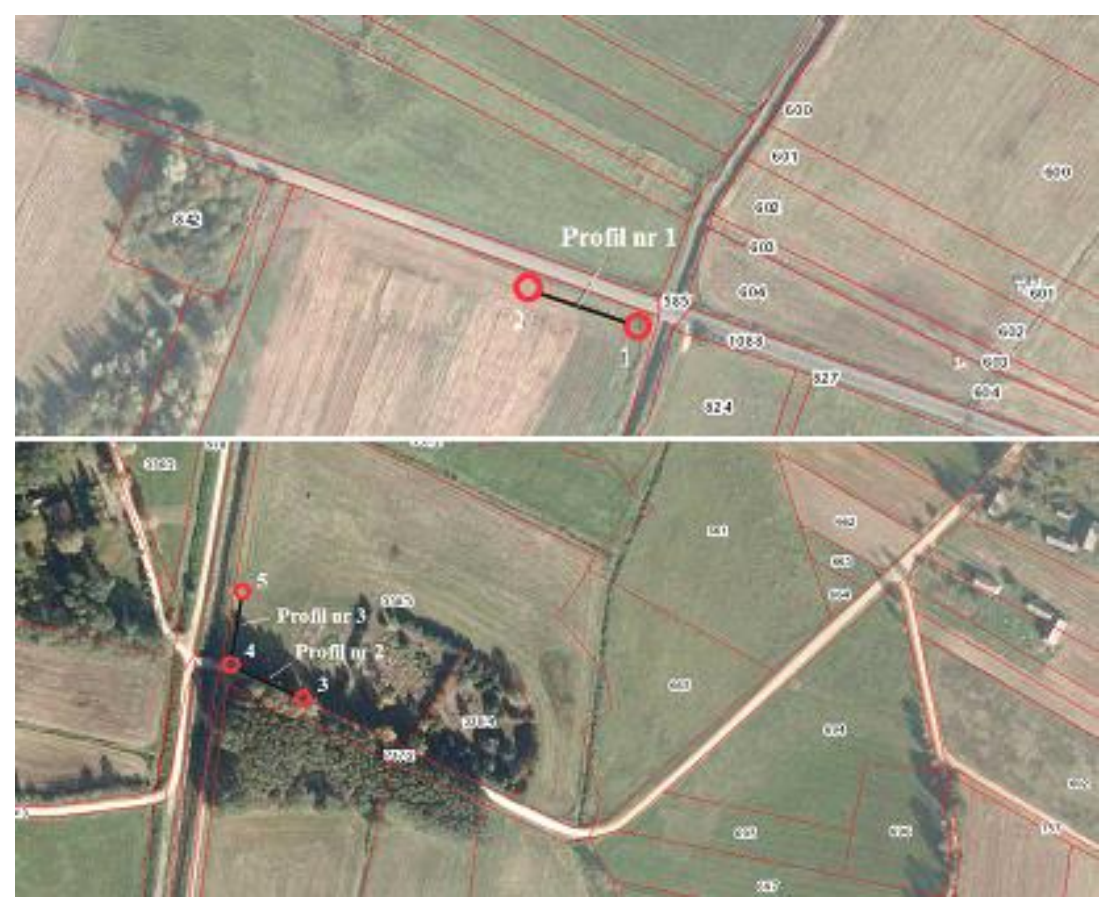

3. The location of research points of Profiles No. 1-3 (based on [11]) 
Profil nr 1

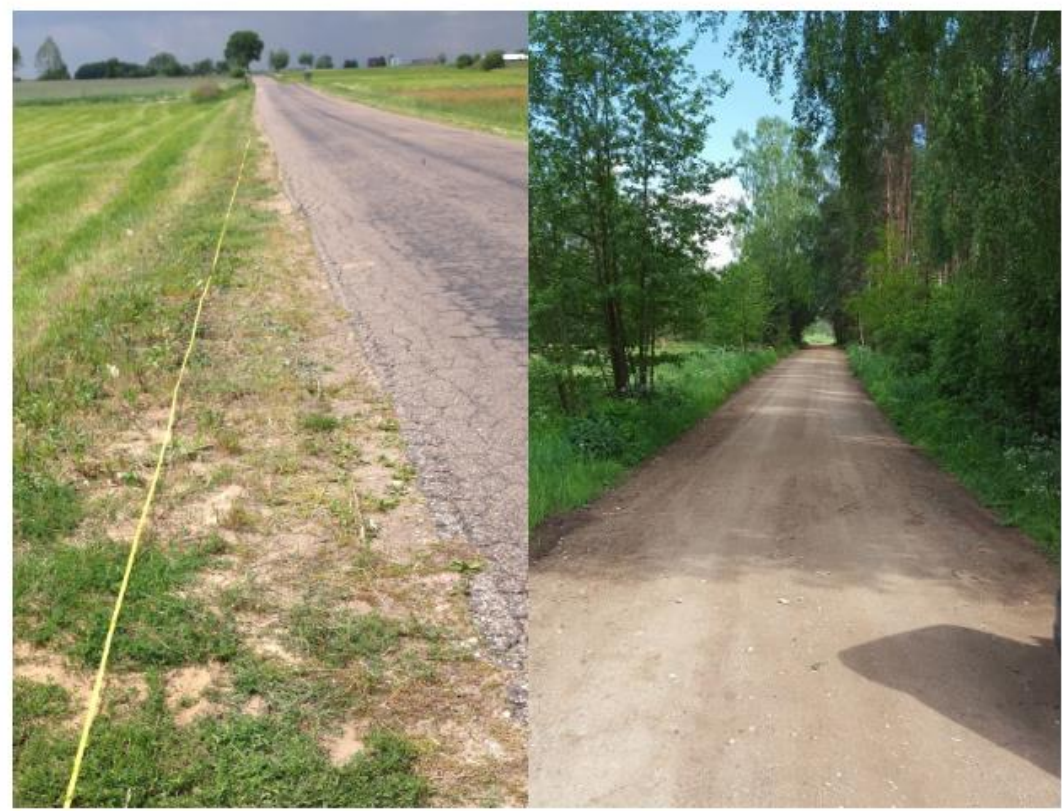

4. A view of the roads affected by the reconstruction plan

\section{Measuring apparatus}

Depending on the anticipated test conditions and the expected results, appropriate equipment and measurement parameters should be selected. In the case of georadar research of the substrate presented in the article, a Latvian georadar named Zond-12e, owned by the Białystok University of Technology, was used. The complete set consists of a central unit connected to a computer, antennas of various frequencies, necessary cables, and wires, and a measuring tape or measuring wheel - odometer (Figure 5).

Before starting essential measurements, one should set out in the field research points, if possible, clean the substrate from elements disturbing the image, e.g. stones, and develop a measuring tape, thus determining the route of the georadar passage on a given profile. The right measurement is best carried out by two people. The operator's task is to switch to a georadar on a given profile while maintaining constant speed and ensuring proper adhesion of the equipment to the ground. These elements are extremely important in the technique of reflective profiling, used to conduct research [2]. When moving the antenna over the profile, time sections are obtained, which then enable the display of geological boundaries. At the same time, the person controlling the measurement should choose the appropriate measurement parameters and pre-interpret the data obtained during the test, which are presented on the computer display during the measurements. The results obtained are saved on the computer's hard drive, which allows subsequent processing and filtration of data. An indispensable element of the radar apparatus is software compatible with the georadar. In this work, the Prism2 program dedicated to the Zond-12e georadar was used. During the calibration of the equipment, the program sends messages about any errors and provides options for solving the problem, which greatly simplifies the work.

The purpose of combining the data obtained from the georadar research was to perform classical geotechnical tests. Ground soil recognition was made using an RKS window sampler with a diameter of $\varnothing 70 \mathrm{~mm}$ and $50 \mathrm{~mm}$, which allowed to precisely determine the hole profile. 


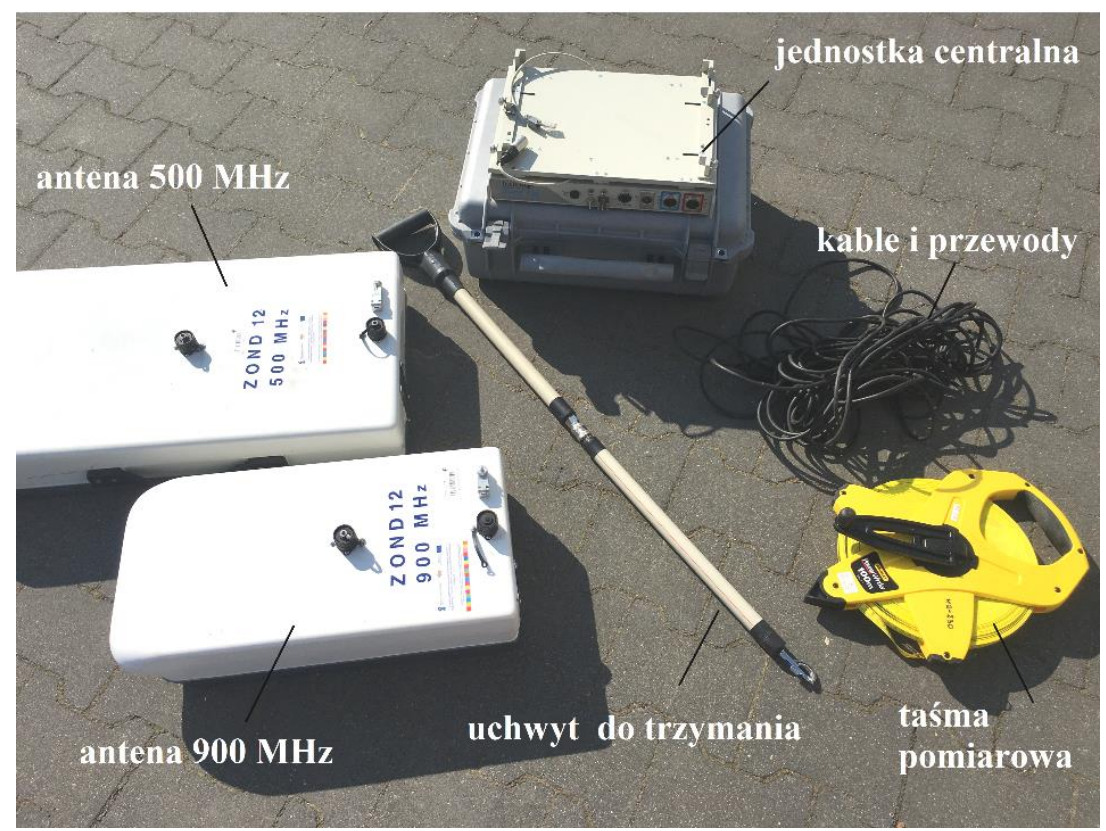

5. Zond-12e Georadar

\section{The results of the study}

Performing soil substrate research as part of road design requires determining the complexity of geotechnical conditions, i.e. recognizing individual subsoil layers and determining water conditions. It is usually sufficient to drill boreholes and perform basic geotechnical investigations, carried out to a depth of about $2-3 \mathrm{~m}$ at a spacing of 20 to $200 \mathrm{~m}$. Large distances between holes, unfortunately, do not allow correct geotechnical sections, often required at the design stage. Even if they are created, they have little to do with reality, especially in areas characterized by a variable geological structure. In a long section, the layering of the layers can radically change, and there may be soil between the holes that were not found in the test points made. A detailed specification of the tests may be possible thanks to the use of the georadar method.

In order to identify the subsoil within the planned road, 5 test holes were created between which 3 radar profiles were marked out. Subsequent georadar passages were made at different output parameter settings. When selecting measurement parameters at the stage of GPR testing, special attention should be paid to the number of samples per scan, time window and amplification. Other characteristics are usually generated automatically, however, it is possible to enter them manually. The type of antenna used is also of great importance, which as previously stated affects the resolution of the method and its depth range. The influence of electromagnetic waves propagated in the ground substrate was tested on the example of 500 and $900 \mathrm{MHz}$ antennas. It has been noticed that the $900 \mathrm{MHz}$ antenna can be successfully used in shallow ground studies, but does not show suitability in deeper layer studies.

The extensive database obtained as a result of the research allowed selection of echograms with the highest visibility and, at the same time, high accuracy of recognition of individual lithological layers. The following echograms were analyzed in detail using an antenna with a frequency of $500 \mathrm{MHz}$ :

- $\quad$ passage No.8 in profile No.1,

- passage No.1 in profile No.2,

- passage No3 in profile No.3.

The images obtained directly from the GPR were digitally processed in a computer program, introducing changes to individual measurement parameters and using filters. 
As a result of classic wells and geophysical surveys, organic soils, mainly peat and other river land that developed in the Holocene, have been found on the site. Due to the low strength parameters, these are soils that should be given special attention during designing. Therefore, echograms obtained as a result of georadar research were interpreted mainly in terms of determining the depth of organic arable lands. The course of depositing the ceilings of organic soils was determined, unfortunately it was not possible to accurately determine the floor of these works. To determine the depth of occurrence of the lower peat layer, an antenna with a different frequency should be used. Nevertheless, the results shown in Figures 6-8 clearly illustrate the limits of peat occurrence in the substrate. In addition, these drawings show the differences between the data obtained by the georadar method and as a result of drillings that did not allow an accurate assessment of the peat ceiling.

a)

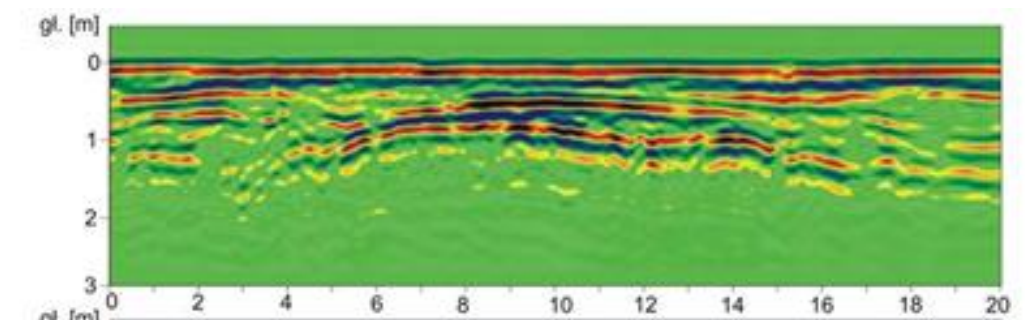

b)

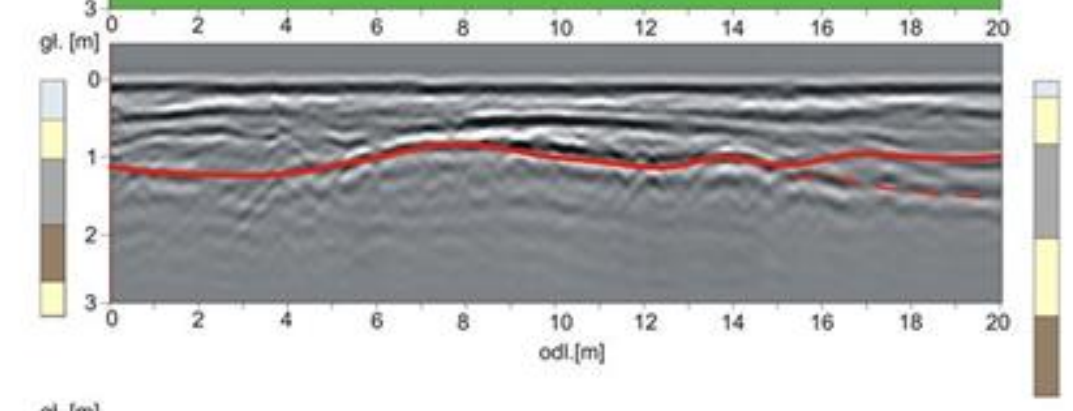

c)

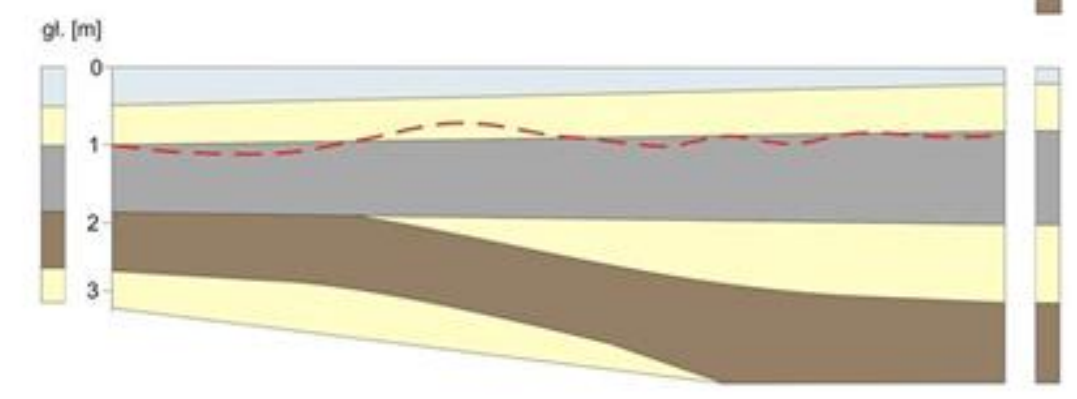

\section{OBJAŚNIENIA:}

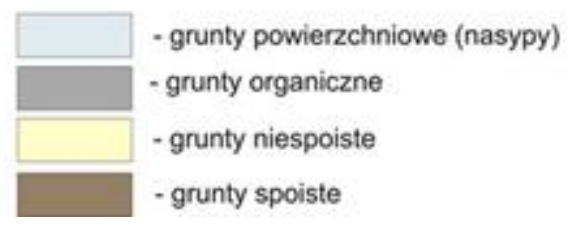

6. Location of the organic soil ceiling in profile No. 1: a) echogram obtained by GPR technique, b) interpretation of the echogram obtained by GPR method with marking of the peat ceiling, c) substrate cross-section made on the basis of drilling 
a)

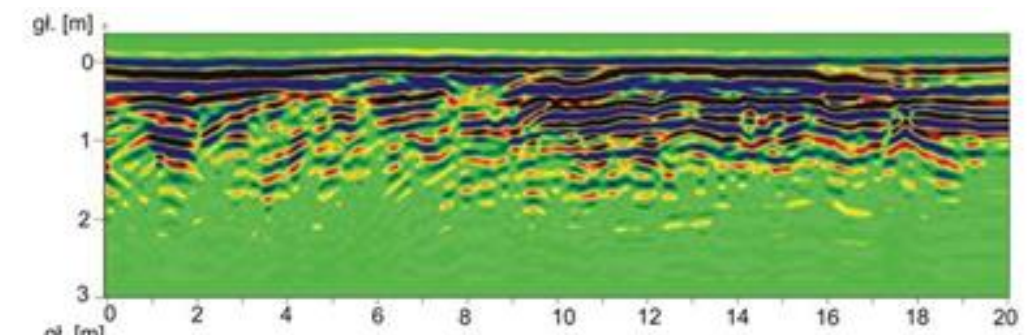

b)

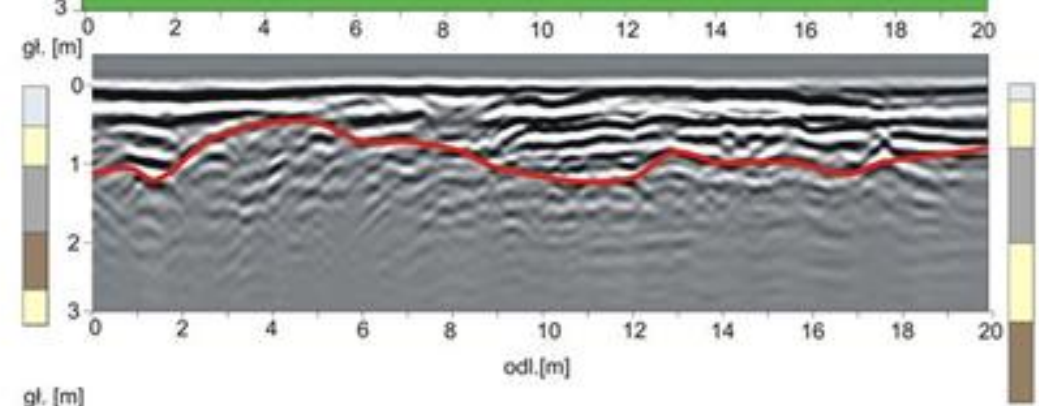

c)

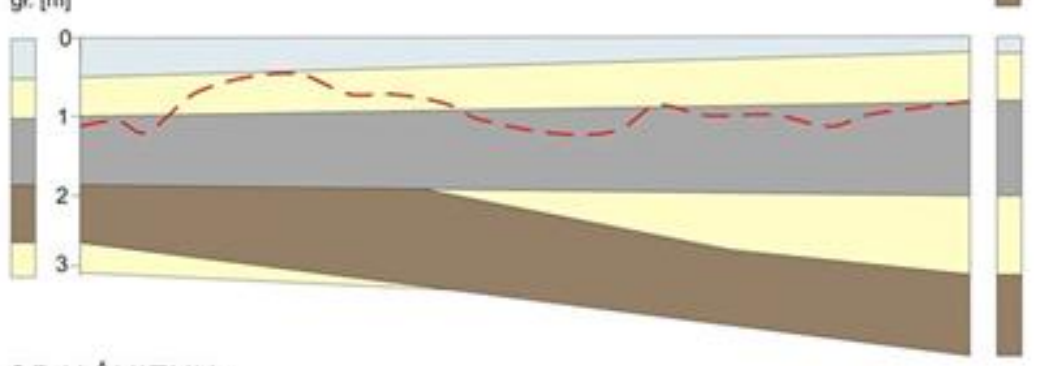

\section{OBJAŚNIENIA:}

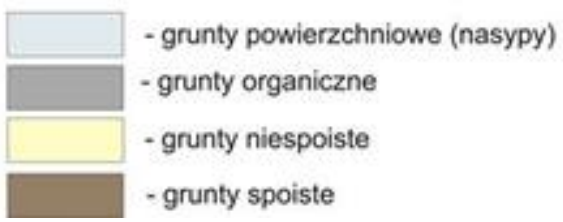

7. Location of the organic soil ceiling in profile No. 2: a) echogram obtained by GPR technique, b) interpretation of the echogram obtained by GPR method with marking of the peat ceiling, c) substrate cross-section made on the basis of drilling 
a)

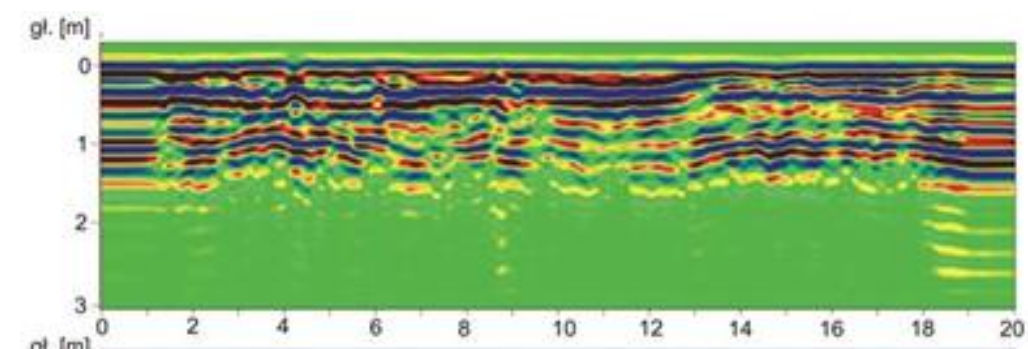

b)

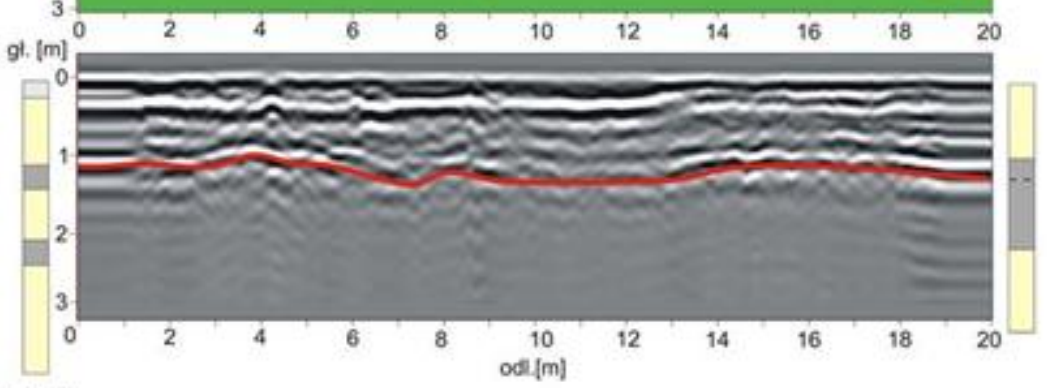

c)

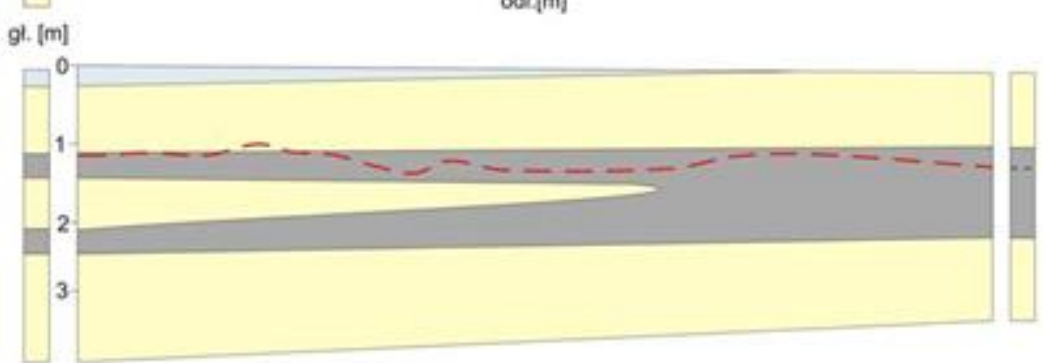

\section{OBJAŚNIENIA:}

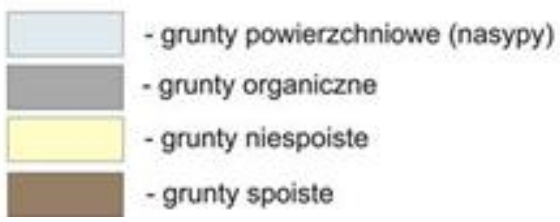

8. Location of the organic soil ceiling in profile No. 3: a) echogram obtained by GPR technique, $b$ ) interpretation of the echogram obtained by GPR method with marking of the peat ceiling, c) substrate cross-section based on drilling

\section{Conclusions}

On the basis of the presented research results, the following conclusions can be drawn:

- it was confirmed that with the increase of the depth range, the resolution of the method decreases, so antennas working at higher frequencies better reflect the structure of shallow layers of ground base; however, the condition of the method's suitability in the ground soil assessment is the correct calibration of the equipment's output parameters;

- GPR method is characterized by greater ease of performing tests, however, difficulties usually occur when interpreting measurements - the knowledge and practice of the person making the analysis becomes necessary;

- georadar is especially useful when a specific type of soil is found in the substrate, characterized by properties significantly differentiating it from the surrounding environment;

- the GPR method cannot replace traditional ground soil testing methods, but it is complementary; knowledge obtained from GPR measurements should be supported by results obtained from other tests performed in parallel in the same area; 
- GPR technique is particularly useful for linear and surface-wide objects, because it helps in the execution of geotechnical cross-sections, i.e. interpreting the arrangement of layers between made holes;

- undoubted advantage is the non-destructive nature of the method; this is a particularly valuable feature in the case of ground soil surveys where the disturbance of the soil structure is undesirable.

\section{Source materials}

[1] Drożdżak R., Twardowski K. Przenikalność dielektryczna ośrodków porowatych czynniki wpływające na jej zmienność. Wiertnictwo, Nafta, Gaz, 2010, T. 27, z. 1-2, 111-120.

[2] Karczewski J. Zarys metody georadarowej. Uczelniane Wydawnictwa NaukowoDydaktyczne AGH, Kraków, 2007.

[3] Łyskowski M., Mazurek E. Analiza konsekwencji doboru nieodpowiedniej prędkości propagacji fal elektromagnetycznych $\mathrm{w}$ trakcie interpretacji inżynierskich pomiarów metodą georadarową. Logistyka, 2013, nr 4, 330-337.

[4] Nawrocki W., Piasek Z. Metody falowe lokalizacji infrastruktury i obiektów podziemnych: teorie, badania symulowane i eksperymentalne. Wydawnictwo Politechniki Krakowskiej, Kraków, 2006.

[5] Olszak J., Karczewski J. Przydatność profilowań georadarowych w interpretacji budowy tarasów rzecznych (dolina Kamienicy, polskie Karpaty zewnętrzne). Przegląd Geologiczny, 2008, vol. 56, nr 4, 330-334.

[6] Ortyl Ł. Badanie przydatności metody georadarowej w geodezyjnej inwentaryzacji struktur i obiektów podpowierzchniowych. Rozprawa doktorska. Akademia GórniczoHutnicza, Kraków, 2006.

[7] Pasternak M. (red.) Radarowa penetracja gruntu GPR. Wydawnictwo Komunikacji i Łączności, Warszawa, 2015.

[8] Rucka M., Lachowicz J. Analiza numeryczna i doświadczalna propagacji pola elektromagnetycznego w badaniach metodą georadarową. Budownictwo i Architektura, 2014, Vol. 13, nr 2, 307-315.

[9] Rucka M., Lachowicz J. Zastosowanie metody georadarowej w badaniach konstrukcji podłogi posadowionej na gruncie. Inżynieria Morska i Geotechnika, 2014, nr 5, 452458.

[10] Sudyka J., Kraszewski C. Sprawozdanie z realizacji pracy pt.: „Ocena geotechniczna podłoża gruntowego techniką radarową $\mathrm{z}$ szczególnym uwzględnieniem stanu hydrologicznego podłoża gruntowego". Sprawozdanie częściowe dla GDDKiA: etap I - zadania 1-6, Warszawa, 2009.

[11] www.geoportal.gov.pl 